\title{
Empowering School Libraries through International Projects
}

\author{
Cláudia Mota
}

Claudia.Mota@agcolmeias.com

Agrupamento de Escolas de Colmeias

\section{Bernardete Francisco}

Bernardete.Francisco@agcolmeias.com

Agrupamento de Escolas de Colmeias

Keywords: Erasmus+, school libraries, Europe, citizenship and ICT

\begin{abstract}
School libraries have no limits, no boundaries, not even for those in rural areas, where cultural opportunities are scarce. In such cases, school libraries themselves become THE opportunities, THE hearts/souls of institutions, HOME for students and teachers engaged in a major journey with other European fellows. This is the story of "Yourope: You in Europe", an Erasmus KA2 project, which, dear reader, you are about to get familiar with.

By enrolling in international projects, you empower your school library and leave traces in your institution and in the citizenship sense of students. The use of the English language comes in a natural way; new ICT tools are used not as an end in themselves, but as a means to achieve certain purposes; the school library resources become fundamental to accomplish the planned tasks. Why did we choose the theme "Europe"? As we will explain in this article... because Europe is all about you and me, and not somebody else.
\end{abstract}

\section{Introduction}

School libraries need to reinvent themselves all the time not to lose sight of the students' interests, but they also need to lead the way in certain ethical and pedagogical areas considered essential at specific moments. Besides, their professionals should not be afraid of taking risks to achieve certain goals.

In fact, defying limits and breaking boundaries were the starting points for this international project, not only physically, but also in a digital and metaphorical sense. The location of our group of schools in a rural area, in the centre of Portugal, tends to limit the cultural diversity available for our community. Agrupamento de Escolas de Colmeias is the name given to a Comprehensive School (with about 386 students aged six to sixteen), two Kindergartens/Primary Schools together, six Kindergartens and four Primary Schools, under the same pedagogical and financial administration. In total, 838 students attend this group of schools, split over an area of approximately twenty kilometres in a rural environment. It is located at almost middle distance between the two biggest Portuguese cities, Lisbon, to the south, and 
Oporto, up north. The nearest city is Leiria, which is sixteen kilometres away from the main school, Escola Básica Integrada (EBI) de Colmeias. The Atlantic Ocean is thirty kilometres away.

There are many students coming from low-income families and with a poor cultural background. This factor makes projects like this even more important. So, students and teachers constantly feel the need to broaden their experience and enlarge horizons. Such an international project - which ended up putting great emphasis in the school library dynamics itself - represented another step in that emancipation process. By empowering the school library, the whole school "grows". Students won't forget their library as the heart/soul of the institution, even when they leave that school to go on with their studies.

"Yourope: You in Europe" is an Erasmus+ project about European history, citizenship, and dilemmas, including contemporary topics such as the refugee question, the sense of European belonging (or the lack of it) and the need for solidarity. Meant for students aged ten to fifteen, "Yourope" officially ends by the end of August 2019, although ideas keep flowing and will, for sure, lead to new initiatives between the involved schools/countries.

Students need to be proactive citizens and to learn about the European Past to understand its Present and Future. To enlarge students' knowledge, conscience and sensibility on such issues was the main aim of this project and the strongest purpose of this IASL presentation is to clarify how it was done. Why? Because we truly think this is a story worth being told, true example of good practices that might stimulate others to deal with similar topics and explore new ideas, physical resources and ICT tools.

By explaining the strategies, activities and difficulties felt, other librarians/teachers will, hopefully, be able to adapt (part of) this project to other contexts/realities and feel inspired to embrace analogous adventures. For us, the writing of this paper also meant a pause to do a balance of this experience. This presentation at IASL will hopefully lead to future connections with other professionals/institutions, willing to cooperate in international projects with our group of schools, placed in a "corner" of Europe... but eager to participate in the transformations occurring in the world.

This is also a story of hard work, resilience and growing enthusiasm, as the school library got more and more important throughout the process. With no special role previously defined, it became the natural place for "Yourope", where digital resources became fundamental, initiatives converged, books and films were discussed, guests invited, personal interests shared and the main products presented/disseminated. A true Home for this project, the school library also provided the emotional atmosphere for a closer relationship between the involved teachers and students, who, as a plus, dared to participate in solidarity campaigns which went as far as Cape Verde.

In fact, IFLA correctly addresses the librarians' fundamental role, by explaining that "to enhance access for all, librarians and other information workers support people in their information searching, assist them to develop their reading skills and information literacy, and encourage them in the ethical use of information (with particular attention to the welfare of young people)" (IFLA, 2016). Thus, this article focuses on the praxis (what / when / how it was done), but also reveals a certain vision of the role of school libraries in growing digital societies, not disregarding their social potential for the benefit of Humankind.

\section{Theme Choice}

International Association of School Librarianship

https://iasl-online.org 
Why did we choose this topic? First of all, we share the educational concern to train young European active citizens with the European Union, whose Strategic Framework for European Cooperation in Education and Training (ET2020) states that the objective of promoting an active citizenship and enhancing creativity and innovation - including the entrepreneurial spirit, in all the levels of training and education - is a Must: "Europe faces a number of challenges that can only be met if it has innovative, well-educated, and entrepreneurial citizens who, whatever their walk of life, have the spirit and inquisitiveness to think in new ways, and the courage to meet and adapt to the challenges facing them" (EC, 2017). Besides, according to the United Nations 2030 Agenda, the fourth Global Goal for Sustainable Development is a "quality education", which means to "ensure inclusive and equitable quality education for all and promote lifelong learning opportunities for all" (WLL, 2016). Thus, this project was part of our contribution to this international concern.

However, this project came essentially from a practical need: most of today's young people know little about what happens in the world and in Europe in particular. Many neither watch the news nor read newspapers. If they do so, they don't understand the main political, social or economic contexts, neither realize the web of events that links us all. Students also need to get familiar with historical facts, which explain how things evolved. To be conscious and well-informed European citizens, they have to comprehend the importance of the Second World War and the Holocaust, plus their devastating effects, as well as the implications those terrible circumstances led to. Although today's context is different, by revisiting the Past we fight against forgetfulness and open a door for a better acceptance of those who are now forced to leave their houses/countries in despair. It's the case of thousands of refugees who escape to Europe every day. Faced with a "new" (old) Europe that receives migrants every day, sometimes in inhuman conditions, we can't be indifferent and have to focus on solutions that preserve the Human Rights. We don't want to compare very different stages from the Past and Present, but to make students realize that there are always limit situations, independently of the context, that let millions of people with no alternatives. However, even in catastrophe Human Integrity should always be preserved.

Some Erasmus + projects place European citizenship/agenda as a collateral topic, but we wanted, from the very beginning, to put it in the centre of attention, committing our students to their role as Europeans. Our motto has always been: this project is all about YOU in Europe and not somebody else, as written in capital letters in the webpage of the project. Thus, we believe it has a strong European added value. Furthermore, some students show strong prejudice towards others, not realizing that their culture, context and experience are just different. So, another aim was to promote a mind broadening, intercultural communication, social inclusion, knowledge of the similarities/differences between cultures and traditions, plus a positive attitude/respect towards others.

As said before, students know little about the political, economic and social agenda of the European countries and have little conscience of the effects that a decision in the European Union headquarters might bring to their own lives. The recent economic crisis felt in many European countries, for instance in Portugal, has dramatically increased job insecurity. Young people are openly pessimistic when asked about their future. However, we are surrounded by opportunities to which we can give innovative answers. So, they need to develop competences in ICT, languages and social skills, as set out by the European Directive for Education. With training and knowledge, all of us can be active citizens and entrepreneurs. We can definitely have a vital attitude to enhance everything we are good at. At a school context, here comes the central role of the library as a vibrant force.

\section{Building the Project}

International Association of School Librarianship

https://iasl-online.org 
We truly believe that with a good focus and planning no project can go wrong: "In order to survive and succeed in the present environment the following need [has] to be embedded in library cultures: a belief in the need for continuous learning, an assumption that all decision-making needs to be strategic, a commitment to the necessity of prioritization of the allocation of scarce resources, and a demonstration of the value of public organizational and individual accountability. Libraries have to be engaged in strategic planning (...)" (Lakos and Phipps, 2004: 351, emphasis added)

To reach the philosophy previously explained we planned the project as follows:

a) first year's theme - "Glocal Europe (balance between what's gloBal and Local)": activities focused on the Past of Europe, to better understand the Present;

b) second year's theme - "What about tomorrow?": activities focused on the Present and Future of Europe and what each of us can do to build a better Europe.

We also defined that the target groups to be addressed would be students aged ten to fifteen because of their English knowledge, level of maturity and capability to discuss serious issues. Based on our previous experience in international projects, we were sure that students would find it very interesting to get to know - by means of reading, sharing videos, playing didactic games and other forms of interaction foreign people who are about their age, but have a different lifestyle. With their teachers' help and the school library teacher/team's help, they would need to find creative solutions for the questions/problems defined. This would make them feel that they can always choose to have a positive attitude in life instead of waiting for someone to give them a solution/answer. It was likewise extremely stimulating and leading to self-improvement to present the work done in each school in the international meetings at European level. Undoubtedly, the strengths that made some partner students stand out in the learning/teaching/training activities were transmitted and experimented by the others in peer to peer work, learning by sharing, observing and taking part in the discussion.

The project was written by us, Portuguese teachers, as we assumed from the beginning the general coordination of the project, but all partners agreed to the planned activities and added suggestions. As to the local coordinating teams, we decided to join school librarians from different countries, based on the previous contact between some of them. There was also an implicit certainty that, like this, the project dynamics would be strong. Gradually and naturally, the school library role as a transversal space for learning emerged. We chose schools from different locations around Europe, permitting an opening effect of the project: diversity of focus and experiences; different typologies of schools (rural and city contexts); common foreign languages taught in the involved schools (to value the international dimension); agreement on the tasks planned (in order to conduct the project successfully); age proximity between students; connections with external entities, so that the project would be as much widespread as possible.

\section{Main Activities}

Let us just describe some of the activities which put great emphasis in the role of the school library. The initial "mysterious class game" put two countries in contact at a time through a Skype session, but the most curious about it was that students from one country had to guess the nationality of their Skype partners by asking yes-no questions. The activity took place in the corresponding school libraries (except in Turkey, where there was no school library in the involved school) and this was the first contact with the library atmosphere (or reading atmosphere) of other European youngsters.

The preparation of students' presentations of books and films about the Second World War/Holocaust was also an excellent pretext to list and analyze all the physical and digital resources about the topic each

International Association of School Librarianship

https://iasl-online.org 
school library possessed and choose those which were suitable for young people. They were the basis for this activity, which also led to the use of ICT tools such as Emaze, Prezi and PowerPoint. Local presentations of these books and films took place in the school libraries, as well as resource exhibitions meant to celebrate the "Day of the Victims of the Holocaust", on 27th January. There were also workshops on digital story telling for teachers/students; the writing of stories about the topic "One month across borders" (using Canva); the digital localization of all schools (with Google Maps); the construction of an interactive map with the most important events, in the involved countries, during the Second World War/Holocaust period (using myHistro); the creation of a "Yourope train" in each school (with a different topic and materials prepared at home); and the elaboration of Mind Maps (with the tool MindMeister). Among other meaningful activities, there were also the celebration of the "Europe Day" (with an "Open day" in each school), the exhibition of the most relevant Erasmus + products and the digital conception of e-cards. To create the e-cards, students used Punchbowl and had to imagine they were refugees in Europe who were writing to their families at home.

The analysis of the "Children's Rights Declaration" led to the creation of Kahoot games, as well as the preparation of a Parliament Discussion on the topic, which took place in transnational groups in Hungary. Games to stimulate self-confidence and the ability to talk in front of an audience, as well as the so-called "Europe on my school wall" (selection of photos to be placed in the last hosting school as a symbol for the last mobility) were also important steps throughout the project course. The path taken was not always straight, there were ups and downs in some activities (which didn't turn out exactly as previously imagined), but the school library was always there as the physical, digital and even psychological centre of it all. As Raúl Proença, a famous twentieth century Director of the Portuguese National Library once said (in 1918), we sensed the school library "not as a sarcophagus of dead thoughts", but as "a lab of living Science" and as a nest of pedagogy, ethics, solidarity and democracy.

\section{Results and Dissemination}

Considering the good physical facilities of the Portuguese school library, it proved a much more versatile space than the classroom. There, Erasmus students could join in different groups and develop creative tasks with the help and supervision of the coordinating teachers. They felt the freedom to circulate and organize work on their own rhythm. They often exhibited their work to students who also use the library regularly (but for completely different reasons). In the school library, they even felt comfortable to engage in a solidarity campaign, indirectly linked to the Erasmus + project and meant to help children in Cape Verde. That is why we couldn't be happier with the results.

The role of the school library as the HEART of the school was reinforced, but there was also an inner transformation of the youngsters. Erasmus students really improved their sense of active citizenship and proactive attitude in the view of the challenges and opportunities that daily life offers, not only in their homeland but also in Europe as a whole. Gradually, they were not afraid of giving their opinion (however different it might be) when trying to solve a problem. They understood that seeking innovative solutions means taking risks and that these, no matter how successful or unsuccessful they may be, build us as human beings. Finally, they became more attentive and improved social inclusion, language speaking competences and group work abilities.

Other results were more expectable from international projects, in general, and from this in particular, such as:

- developing one's knowledge about the European Union, its history, institutions and current challenges; - valuing Europe as a common precious territory, by turning our differences into strong ties between us;

International Association of School Librarianship

https://iasl-online.org 
- understanding how important it is to learn foreign languages in order to communicate with other people around the world;

- acquiring new ICT competences in an interdisciplinary approach, due to the quantity/quality of the digital tools and platforms used, also including Padlet, Spiral, Lucidpress, Enginestart, among others; - regarding school (and the library in particular) in a more engaged way, moved by the dynamics of the project and getting a better knowledge of other (and one's own) educational system and country.

In the Portuguese case, the headmaster's team and the school library team always gave an important background support to the Erasmus teachers and students, not only in the development of the activities, but also in their dissemination. Across all the involved countries, many news about this project were released in the media (newspapers, magazines and even TV), social networks, project and school bulletin boards, eTwinning platform, website, etc. Having mostly librarians involved in the project was an advantage as they spread the news to local, national and international librarians' communities, reinforcing the potential of school libraries to/in Erasmus + and other intercultural programmes.

During the transnational meetings (just for teachers) and the learning/teaching/training activities (for students and teachers), visits to different types of libraries were also included. Seeing a Portuguese or Hungarian school library, a Romanian historical library, a Finnish extra-modern public library or a Turkish university library with our own eyes (and having the students with us there) is an experience we won't forget. Why? Because we had the chance to get familiar with the virtues and difficulties of the public service each of them has to offer, valuing what we have achieved in our own case/country more and more, but keeping an open mind to the world around us.

Even if restricted to the virtual world, at last, dear reader, we cannot resist to invite you to have a look at the project website, eTwinning page and Facebook group page, where the main ideas, results, methodologies and experiences of the project are collected and will stay so for, at least, five years ahead.

\section{Conclusions}

"As gateways to knowledge and culture, libraries play a fundamental role in society. The resources and services they offer create opportunities for learning, support literacy and education, and help shape the new ideas and perspectives that are central to a creative and innovative society" (White, 2012). In this process, school libraries play a vital role because they directly deal with the new generations. Thus, we firmly believe that the Erasmus+ project "Yourope: You in Europe" contributed to the development of high quality skills and competences of which Europe and its young citizens are very much in need: the promotion of a democratic education, a sense of tolerance and understanding towards others, as well as a strong respect for their beliefs, culture and context. These European values, as well as some knowledge of the past events, are fundamental if we want to give our students a good education and prepare them to be proactive citizens in national and international contexts. We were happy to conclude that these purposes were highly achieved, as we could verify from the informal feedback from participants, as well as from the intermediate and final questionnaires that were filled in by both teachers and students.

For the students involved, Europe ceased to be an abstraction and became the face of hundreds of people more and more familiar as long as the project progressed, and afterwards. Different living ways and unfamiliar languages became clearer and clearer and will, hopefully, be a starting point for various professional and personal projects. The notions of European belonging, political/economic forces, human rights and democracy won't be something indistinct any longer, something just slightly heard of in "school benches", but a new way of thinking and of understanding life, common to all participants. The

International Association of School Librarianship

https://iasl-online.org 
nest for this growing knowledge was the Library, which became, in many ways and throughout the project, the "house of democracy" and the place of excellence for citizenship, debate and acceptance. It was also a true Makerspace, where collaborative work came naturally, ICT tools were tried, flexible tasks were carried out, personal challenges faced and a lot of pleasure shared.

Something like this cannot be done without having emotions involved. So, the school library became a place of affection, openness to others, personal growth and self-discovery. Good memories of Yourope will remain, and new international projects will certainly arise. Due to its tremendous potential, the school library will always be included as a crucial piece of the puzzle.

\section{REFERENCES}

European Commission (EC), 2017. European Policy Cooperation (ET 2020 framework). https://ec. europa.eu/education/policies/european-policy-cooperation/et2020-framework_en (accessed July 24, 2019).

European Commission (EC)/EACEA/Eurydice, 2018. Home Education Policies in Europe: Primary and Lower Secondary Education. Eurydice Report. Luxembourg: Publications Office of the European Union (accessed May 24, 2019).

European Literacy Network (ELN), 2018. Intergeracionalidade e o Mundo Digital: Propostas de Atividades/Intergenerationality in a Digital World: Proposals of Activities. https:/www.is1401 eln.eu/fotos/editor2/imagens/digitalactivities.pdf (accessed June 23, 2019).

IFLA. IFLA Code of Ethics for Librarians and other Information Workers (short version), 2016. https://www.ifla.org/publications/ifla-code-of-ethics-for-librarians-and-other-information-work ers--short-version- (accessed Jul 20, 2019).

Lakos, Amos; Phipps, Shelley. Creating a culture of assessment: A catalyst for organizational change. Portal - Libraries and the Academy. 4(3) [Online] 2004, 345-361. https://escholarship.org/uc/item/0843106w (accessed June 29, 2019).

Rede de Bibliotecas Escolares - Ministério da Educação e Ciência (RBE - MNE), 2013. Programa Rede de Bibliotecas Escolares. Quadro estratégico: 2014-2020. http://www.rbe.min edu.pt/np4/np4/?newsId=1048\&fileName=978_972_742_366_8.pdf (accessed June 29, 2019).

Rede de Bibliotecas Escolares (RBE), 2017. Aprender com a Biblioteca Escolar: Referencial de aprendizagens associadas ao trabalho das bibliotecas escolares na educação pré-escolar e nos ensinos básico e secundário. http://www.rbe.min-edu.pt/np4/file/1906/referencial_2017.pdf (accessed July 10, 2019).

White, Ben. Guaranteeing Access to Knowledge: The Role of Libraries. Wipo Magazine [Online] 2012, 4, https://www.wipo.int/wipo_magazine/en/2012/04/article_0004.html (accessed May $31,2019)$.

World's Largest Lesson (WLL), 2016. Sustainable Development Goals.http://worlds1 argestlesson.globalgoals. org/global-goals/quality-education/ (accessed July 25, 2019). 
Yourope: You in Europe (2016). http://www.erasmusplusyourope.com/ (accessed June 20, 2019).

Yourope: You in Europe eTwinning Twinspace (2016). https://live.etwinning.net/projects/p roject/151583 (accessed June 20, 2019).

Yourope: You in Europe Erasmus + KA219 Project Facebook Group Page (2016). https://www. facebook.com/groups/117482255606326/ (accessed June 20, 2019).

\section{Biographical Notes:}

Cláudia Mota is an English teacher, coordinator of the two school libraries and the Reading Plus project. She was the general coordinator of this Erasmus+ project, as well as a local coordinator of a previous Comenius project. She is an active teacher, likes to be involved in new challenges and constantly learns about Teaching Methodologies, ICT, Foreign Languages and Literature. She finished her PHD in Modern Languages and Literatures in 2015, by Coimbra University, where she had also finished her Master in English studies. She also has a Post-graduation in Translation, another in Animation of Libraries and a third one related to the Management of School Libraries. Her Ph.D Thesis was adapted to book format and published (2016), as it is a good tool for those interested in the potentialities of Children's Literature in Education. She has some articles/papers published in paper and digital format. She is frequently invited to present her investigations/projects in regional/national events in secondary schools and universities.

Bernardete Francisco is a French and Portuguese teacher and belongs to the ICT school team. She belongs to the Erasmus + general coordinating team, as well as to the previous Comenius project. She has taught Drama, incorporating foreign language activities in Drama classes. She also belongs to the Reading Plus team. She is an active teacher, likes new challenges and constantly tries to implement new technologies in language classes. She has a Master in Didactic Methods in Languages. She was responsible for the SELF project (linguistic and non-linguistic) and frequently attends workshops on ICT. She has developed many eTwinning projects in the last years. She attended the MOOCs "Developing skills in your classroom" and "Future Classroom Lab", by the Portuguese Ministry of Education. 